\title{
The Wayang Beber Pacitan Illustration Style for The Development of Character Figures for Millennial Generation Segmentation
}

\author{
Basnendar Herry Prilosadoso ${ }^{1}$, Bagong Pujiono ${ }^{2}$, Siti Supeni ${ }^{3}$, \\ and Muhammad Shafrizal Fajar Maulana ${ }^{4}$ \\ ${ }^{1}$ Faculty of Art and Design, Indonesian Art Institute (ISI) Surakarta \\ ${ }^{2}$ Faculty of Performing Arts, Indonesian Art Institute (ISI) Surakarta \\ ${ }^{3}$ Faculty of Education, Slamet Riyadi University (UNISRI) Surakarta \\ ${ }^{4}$ Faculty of Art and Design, Indonesian Art Institute (ISI) Surakarta \\ 1basnendart@yahoo.com, 2bagong_puji@yahoo.com, ${ }^{3}$ peni.unisri@yahoo.com, \\ ${ }^{4}$ muhammadshafrizal67@gmail.com
}

\begin{abstract}
This research uses descriptive qualitative research with the main focus to describe and explain the role of animation as an alternative to the development of traditional arts. Particularly in the process of creative development of imagination, and exploration of techniques, including the use of modern technology and illustration, this aims at alternative media for preservation and diversification, especially to the sophisticated to create certain effects. This development makes illustration as an art form that not only conveys messages but can be enjoyed as a form of art that has certain elements of beauty and satisfaction. Stages of analysis through various sources generated from information both from literature review and interviews are carried out using models interactive, where each component of the analysis includes the stages of data collection, data reduction, presentation, and drawing conclusions. Through data triangulation techniques in the form of triangulation of data sources and theory triangulation as a benchmark in supporting the data validity test stage. The results of the study in the form of wayang beber character studies can be applied in audiovisual and other media and can be explored further and developed in the future so that traditional arts can develop along with the times.
\end{abstract}

Keywords: Character, Puppet Beber, Illustration, Preservation, and Millennial Generation

\section{INTRODUCTION}

In this era of globalization, there is a growing fear that cultures around the world will become more uniform, leading to a decline in cultural diversity. To overcome this potential homogeneity, strategies have been developed to preserve cultures whose existence can be threatened [1]. Indonesian culture is inseparable from the dynamics and developments caused by the flow of pre-modern post-modern culture. The last decade of this century is in two contexts which shape and shape the current cultural figure, the process of modernization and globalization. Ideas, patterns of behavior and prejudice intersect and clash and synthesize to produce new cultural 
elements [2]. The regional culture at this time feels critical because it is displaced by modern culture from the west. The presence of digital media changes the world and the way we think about ourselves and the universe. Specifically, digital culture is associated with the speed of social change and technological transformation in a short time [3]. Slowly the community begins to leave the local culture which actually has a deep meaning. Hedonism and individualism are inherent in people's lives, especially the younger generation [4]. Society considers regional culture an ancient thought that is not appropriate in the current context. Culture is no longer a filter of the times, but a mere memory [5]. Culture of hedonism and individualism hit people's lives, especially among the millennial generation. The millennial generation is an emerging generation and will soon become the dominant workforce in Indonesia. Unfortunately, millennial generation is highly motivated in Indonesia, where this millennial is a new problem for human resources because it has different characteristics compared to its predecessor. [6]. The generation of Indonesian millennials is more vulnerable to the entry of change and influence from the west. Solutions to ward off or reduce the culture, one of them through traditional arts and culture, where one of them through wayang.

The application of local wisdom models and ways of community adaptation in living with the natural atmosphere is a local cultural behavior, which revealed the way of life of the people who still adhere to local customs [7]. Traditional art performances are usually associated with religious activities, affirmation of social integrity, education and aesthetic pleasure experienced by commanders and royal families. Traditional art is a cultural product passed down from generation to generation and it lasts a long time and is often anonymous [8]. Wayang kulit performances contain high-quality arts and crafts, which consist of a variety of media such as painting, sungging, and wayang performances also bringing together visual arts, musical instruments, vocals, drama, literature, and dance, as well as puppetry arts that require skills to animate the character of the shadow puppet [9]. Puppet has existed, grown and developed for a long time until now, crossing the long journey of Indonesian history. The puppet tradition with the adaptation of Mahabharata and Ramayana episodes in Indonesia's valuable culture that has been recognized by UNESCO since 2003. Its stories and characterizations serve as models for learning philosophy, moral ethics, and character for young people. [10]. Indonesian Puppet on November 7, 2003 has been named by UNESCO, that as a Masterpiece of the Oral and Intangible Heritage of Humanity, or a Cultural Master of Peace of the World. By the world, the existence of wayang is recognized as a masterpiece of non-material world culture, so that it is hoped that wayang will get a positive response and demand from the public, especially the younger generation. [11].

The durability and development of this puppet have been tested in facing various challenges from time to time with the content of local wisdom that always accompanies wayang travel in every time. This long wayang journey has been tested in facing various challenges from time to time. Through the development of an increasingly globalized world, capable of displaying the durability and ability to anticipate the development of that era, the shadow puppets managed to achieve high-quality art [12].

Wayang Beber art, including relatively old age that is derived from the end of the Hindu era in Java. At first Wayang Beber paints Wayang stories from the Mahabharata epic, but then switches to Panji stories originating from the kingdom of Jenggala in the XI century and reaches its heyday in the Majapahit era around the XIV-XV century [13]. The development of the Pacitan wayang beber traditional art has suffered a setback and lacks a touch of creativity so it does not attract the attention of the public at this time. 


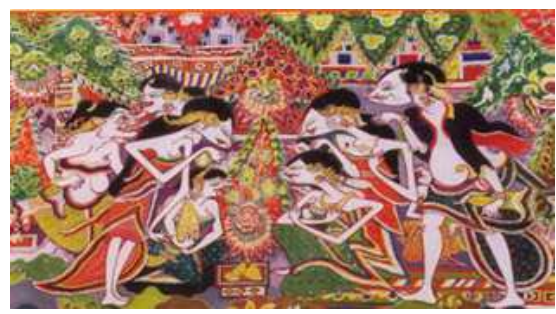

Fig. 1 Wayang Beber Pacitan

Source : Basnendar H Documentation, 2019

As one form of performance art, Pacitan's wayang beber has a story element that is full of romance, but if the packaging of the show is not adjusted to the tastes of the people at the moment the performances and stories in it are difficult to enjoy. One of the efforts to re-actualize traditional art is to create a new traditional art form in Indonesia to attract public interest. This new form is certainly adjusted to the public interest. Traditional art is art that has standard forms and rules. A new form of traditional art is proposed by creating traditional art innovations without changing and changing the standards and essence of traditional art. Changing the form and packaging of traditional art performances into contemporary art without losing the essence and soul of traditional art [14].

Efforts to raise the existence of wayang beber, one of them by giving a touch of fine art that can give value to the appearance of the puppet characters, illustrative techniques of developing Pacitan wayang characters can be done through several stages so that the embodied character does not leave the soul of the wayang beber. For this reason, it is important to develop a tool that can bridge the wayang beber tradition and art lovers, especially the younger generation. The development of the wayang beber animation media is expected to attract the interest of the younger generation to enjoy and appreciate the traditional arts, one of which is the wayang beber.

\section{METHOD}

The stages of this research were carried out in several stages, namely: stages of problem solving, stages of planning, stages of design, stages of trials, and the final stages of dissemination. The purpose of this study is to develop the character of the wayang beber characters so that Pacitan is easily accepted by the younger generation and can also be accepted by the times. The process of studio field observations and interviews with various sources, namely, academics, puppeteers and design integration. Furthermore, as a test of data validity through data triangulation techniques so that the results obtained can be more leverage. The triangulates technique used is the triangulation of data sources and theories. Data analysis techniques use interactive chain analysis with steps including data collection, data reduction, data presentation, and drawing conclusions [14].

\section{RESULT AND DISCUSSION}

\subsection{Character Illustration as an Element for Wayang Beber Character Development}

Throughout our lives we are always taught how to read words and interpret them, then we are shown how sentences are made up of grammar, how authors compose words to form meanings to each other, and how these meanings are made and communicated very 
sophisticated. [15]. The term illustration comes from the Latin language "illustrate", which means to explain something, then the illustration is a picture used to explain or explain something in the form of text, stories, circumstances, scenes, or events through a picture so that it will make writing or information easy to understand. A good illustration must meet several requirements, including being communicative, meaning that it is easy to understand and understand so that the message delivered can be well received, must be informative, it means to provide information about the message to be delivered, not complicated, and the making must be adjusted to the theme or message that will be delivered. It was also stated that there were three meanings of illustrations, namely: (a) pictures in the form of photographs or paintings to help clarify the contents of the book; (b) drawings, designs, or diagrams for decorating cover pages; and (c) additional explanations in the form of examples to further clarify the exposure of the writing.

Illustration of character according to Pardew (2004: 153), that works of art that focuses on a character that aims not only to determine the appearance of the character but also its behavior and nature. When creating illustrations of characters, illustrators must consider the character's personality [16]. Character design is not just about pictures or models but always keeps messages, ideas, philosophies and even certain ideologies so that it can be a reflection of the social conditions of the community where the work was born [17]. The serious design of the characters to illustrate the character of the wayang beber can also influence the condition of social psychology towards improvement if used appropriately.

\subsection{Wayang Beber Pacitan}

Wayang Beber are included in the category of puppet art that developed since the days of the Majapahit Kingdom. Some types of puppets in Indonesia, wayang beber including the most unique puppets, because it has a special form of performance by displaying pictures as objects of performance. Pictures of wayang beber, painted in such a way on paper or cloth, are made one scene after another in succession using a traditional painting technique called sungging technique which is very good, careful, through and has a specific style. [18]. The art performance of Pacitan wayang beber that has been passed down by the puppeteer, the form and meaning that takes place takes place regularly and tries to be maintained with a view to maintaining its existence as happened in the ritual procession. The ritual procession itself is also found in this traditional performance, for example when before the music is played as a marker of the game, the puppeteer must perform the ritual and provide certain offerings or offerings in the form of cone or ambengan and burn incense.

Wayang Beber that have been in a very long period of time have proven to have endurance and the development of this puppet has been tested in facing challenges from time to time with the content of local wisdom that always accompanies wayang travel in every time. The wayang beber is one type of puppet, which is found in Java made of long paper, and is depicted (painted) episodes of stories that are staged in the form of a picture show that is held (unfolded) and not in the form of a shadow (shadow play) like a shadow puppet purwa. Wayang Beber include speech theater performances with the object images spoken, or pictures told. [19].

The wayang beber performance is carried out by presenting a narrative story (such as storytelling) and a demonstration of the scrolls of the exposed pictures. The scenes (episodes) in the picture scroll depict the events of the story taken from folklore around the romance of Raden Panji Inu's kertapati with Galuh Candrakirana. The series of drawings depict the sequence of scenes from a play that consists of various stages. Each round consists of several scenes painted on a roll of paper or cloth. [20]. 


\subsection{Design Method of Illustration of Wayang Beber Character}

The stages of applied research are carried out in several stages, namely: the stages of inspiration, the identification of problems, the stages of conceptualization, the stages of exploration, and finally the stages of definition. The design method uses the Design Process (Karl Aspleund, 2010) which consists of 5 (five) stages [16], that is :

\subsubsection{Inspiration}

This stage with the process of gathering various information and impulses as material for inspiration, especially visual data in the form of a variety of wayang beber in Indonesia both from print and audiovisual media.

\subsubsection{Identification}

Next to the identification stage, a problem or project is constrained. The goal is to limit the problem to function as a corridor so that the solution to the problem does not widen and lead to the right solution. The purpose of this stage is to identify the use of illustrations in the development of beber puppet characters and segmentation for millennial generation.

\subsubsection{Conceptualization}

The stages of conceptualization will be carried out a study of the concept of design, including reviewing appropriate methods to achieve a solution so that a thought structure is formed. Conceptualization can be realized with a brainstorming process, namely by reviewing concepts, exploring the boundaries of problems that have been made previously, and describing the elements of the concept.

\subsubsection{Exploration}

Then in this exploration stage sketches will be carried out to obtain the various possibilities that exist so as to produce various alternatives, however, the results are. Various alternative sketches of Beber wayang character illustrations were made in this exploration stage.

\subsubsection{Definition}

It is a decision making stage by considering practical and conceptual aspects. At this stage ideas/concepts begin to appear as objects. The determination and making of a model will be an illustration or representation of design concepts. After being tested and deemed to meet the criteria and standards, the prototype of the beber wayang character was disseminated to several government agencies, such as the cultural department, elementary school, junior high school, and senior high school in Pacitan Regency to be used as a medium to introduce the traditional wayang beber arts to the millenials generation.

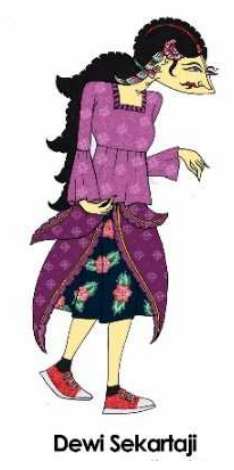

Fig. 2 Alternative Illustration of Wayang Beber's Character Pacitan Dewi Sekartaji Source: Bening Tri Swasono, 2019 
Dewi Sekartaji's character is displayed in a character that is favored by the younger generation, where costumes are worn as a collaboration between modern and old style. The appearance of Dewi Sekartaji looks more relaxed and casual with the use of sneakers and the characters look more human, so that it is expected to be accepted by the millennial generation. The identification of puppet characters can collaborate as an alternative medium that is in line with the segmentation of young people. [21] [22].

\section{CONCLUSION}

Identification of the wayang beber art shows that traditional art can be collaborated into a character that can be accepted by millenials. Through illustration changes. The results of this applied research are in the form of developing wayang beber characters through stages, namely: Inspiration, Identification, Conceptualization, Exploration, and Definition. Character development through the wayang beber illustration style can be an alternative and the effort to develop and preserve the traditional wayang beber art in the future. The role of the three aspects, namely: the community, government, and universities to work together in maintaining the existence of Pacitan wayang beber. In the future there is still much that can be developed both from the visual aspects, performances, stories, packaging, and other aspects contained in this Pacitan puppet show so that the traditions of the ancestral heritage can follow the development of the age and be accepted by future generations.

\section{REFERENCE}

[1] S. Pietrobruno, "Cultural Research and Intangible Heritage," Cult. Unbound J. Curr. Cult. Res., vol. 1, no. 1, pp. 227-247, 2009.

[2] N. Y. D. Adisasmito, "Wujud Visual Gambar Pada Naskah Tua Nusantara Sebagai Refleksi Intelektualitas Leluhur Bangsa,” Panggung, vol. 22, no. 3, pp. 306-318, 5676.

[3] F. Darmawan, "Modalities Visual Kartunis dalam Kartun Politik Online Pascareformasi," J. ILMU Komun., vol. 13, no. 1, p. 109, 2017.

[4] B. H. Prilosadoso, N. R. A. Candra, D. Atmaja, and S. Murwanti, "Cartoon Character in Animation Media for Preserving Folklore Traditional Art in Surakarta," in Proceedings of the 1st Seminar and Workshop on Research Design, for Education, Social Science, Arts, and Humanities, SEWORD FRESSH 2019, April 27 2019, Surakarta, Central Java, Indonesia, 2019, pp. 1-6.

[5] A. Rachmadian, "Pengaruh Masuknya Budaya Asing Terhadap Pelestarian Kebudayaan Tari Tradisional Wayang Topeng Malangan Di Malang Raya, Jawa Timur,' J. Pariwisata Pesona, vol. 1, no. 2, pp. 6-21, 2018.

[6] A. Frian and F. Mulyani, "Innovative Issues and Approaches in Social Sciences, Vol. 11, No. 3 | 1," Innov. Issues Aproaches Soc. Sci., vol. 11, no. 3, p. 90, 2018.

[7] G. Gunardi, "Peran Budaya â€ Mikanyaah Mundingâ€ $€^{\mathrm{TM}}$ Dalam Konservasi Seni Tradisi Sunda," Panggung, vol. 24, no. 4, 2014.

[8] E. W. Suprihatin Dyah Pratamawati, "Malang Mask Puppet Presentation Structure Arrangement of the Story Rabine Panji as Cultural Tourism Commodity in Malang Regency East Java," Harmon. J. Arts Res. Educ., vol. 16, no. 1, p. 66, 2016.

[9] W. N. R. W. Ramli and F. 'Aini Lugiman, "The Contribution of Shadow Puppet's Show through Engaging Social Communication in Modern Society," Procedia - Soc. Behav. Sci., vol. 35, no. December 2011, pp. 353-360, 2012.

[10] M. Isa and P. Koesoemadinata, "Visual Adaptation Of Wayang Characters In Teguh Santosa’s Comic Art Adaptasi Pola Visual Tokoh-Tokoh Perwayangan,” vol. 33, no. 
3, pp. 401-408, 2018.

[11] B. Sutedjo, Agus \& Herryprilosadoso, "Perancangan Desain Permainan Materi Pendidikan Anak Usia Dini Berbasis Wayang Beber," Acintya J. Penelit. Seni Budaya, vol. 8, no. 1, pp. 17-24, 2016.

[12] B. Herryprilosadoso and Handriyotopo., Suyanto, Rosmiati, Ana., "Identitas Visual Desa Wisata Batik Cokrokembang Melalui Environment Graphic Design Sebagai Pengembangan di Kabupaten Pacitan," Acintya J. Penelit. Seni Budaya, vol. 9, no. 1, pp. 17-22, 2017.

[13] W. Nurcahyono, "Penciptaan Teater 'Jaka Kembang Kuning," J. Urban Soc. Arts, vol. 4, no. 2, pp. 110-122, 2018.

[14] D. Sulaksono, K. D. Wijayanti, and B. W. Setyawan, "Wayang Multimedia : Wayang Contemporary Art as a Creative Art-Industrial in Modern Era," in Proceedings of the 1st Seminar and Workshop on Research Design, for Education, Social Science, Arts, and Humanities, SEWORD FRESSH 2019, April 27 2019, Surakarta, Central Java, Indonesia, 2019.

[15] D. W. Suwardikun, "Persuasi Melalui Ilustrasi dalam Iklan Cetak Sampling dan Metode Pengambilan sampling secara purposive dengan memperhatikan kriteria," vol. 3, no. 2, pp. 129-136, 2009.

[16] Herlina Kartaatmadja, "Studi Ilustrasi Karakter Anak Indonesia Untuk Rekomendasi Pembuatan Buku Cergam Anak," 2015, pp. 145-159.

[17] D. Hilman and T. Zufri, "Desain karakter berbasis pada wanda wayang bima," Desain, vol. 06, no. 01, pp. 41-53, 2018.

[18] T. R. Rohidi and D. S. Kartika, "The Journal of Educational Development Values of Character Education Contained in Wayang Beber Pacitan Performance," J. Educ. Dev., vol. 6 , no. 36 , pp. $67-78,2018$

[19] Suyanto, "Menggali Filsafat Wayang Beber untuk Mendukung Perkembangan Industri Kreatif Batik Pacitan,” Panggung, vol. 27, no. 1, pp. 87-98, 2017.

[20] B H Prilosadoso, N.R.A. C.D. Atmaja, S. Murwanti, Dharsono, Guntur, and B W Setyawan, Cartoon Character in Animation Media for Preserving Folklore Traditional Art in Surakarta. in Proceedings of the 1st Seminar and Workshop on Research Design, for Education, Social Science, Arts, and Humanities, SEWORD FRESSH 2019, April 27 2019, Surakarta, Central Java, Indonesia. EAI ISBN 978-1-63190-193-5. ISSN 2593-7650. DOI: 10.4108/eai.27-4-2019.2286814. pp. 2, 2019.

[21] S H Heriwati, B H Prilosadoso, B Pujiono, Suwondo, dan A N Panindias. 2019. 3D Puppets Animation for Encouraging Character Education and Culture Preservation in Surakarta. International Journal of Engineering and Advanced Technology (IJEAT), Volume-9 Issue-1. DOI: 10.35940/ijeat.A1341.109119. pp. 1551. 2019.

[22] B.W. Setyawan and K. Saddhono, "Eret traditional ceremony as representation of spirit of mutual cooperation among coastal communities". Adv. Sci. Let. vol. 23 no.10, pp 9991-9992, 2017 